\title{
Hypothetical orchestrated cooperation between dopaminergic and kinin receptors for the regulation of common functions*
}

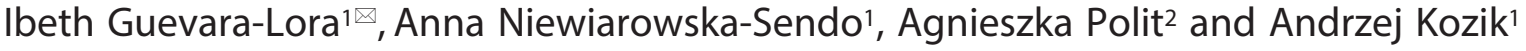 \\ 1Department of Analytical Biochemistry, Faculty of Biochemistry, Biophysics and Biotechnology, Jagiellonian University in Krakow, Kraków, \\ Poland; ${ }^{2}$ Department of Physical Biochemistry, Faculty of Biochemistry, Biophysics and Biotechnology, Jagiellonian University in Krakow, Kraków, \\ Poland
}

The G protein-coupled receptors (GPCRs), one of the largest protein families, are essential components of the most commonly used signal-transduction systems in cells. These receptors, often using common pathways, may cooperate in the regulation of signal transmission to the cell nucleus. Recent scientific interests increasingly focus on the cooperation between these receptors, particularly in a context of their oligomerization, e.g. the formation of dimers that are able to change characteristic signaling of each receptor. Numerous studies on kinin and dopamine receptors which belong to this family of receptors have shown new facts demonstrating their direct interactions with other GPCRs. In this review, current knowledge on signaling pathways and oligomerization of these receptors has been summarized. Owing to the fact that kinin and dopamine receptors are widely expressed in cell membranes where they act as mediators of numerous common physiological processes, the information presented here sheds new light on a putative crosstalk of these receptors and provides more comprehensive understanding of possible direct interactions that may change their functions. The determination of such interactions may be useful for the development of new targeted therapeutic strategies against many disorders in which kinin and dopamine receptors are involved.

Key words: kinin receptors, dopamine receptors, G protein-coupled receptors, oligomerization, signaling pathways

Received: 29 March, 2016; revised: 23 May, 2016; accepted: 06 June, 2016; available on-line: 02 August, 2016

\section{INTRODUCTION}

Kinin and dopamine receptors belong to the class A (Rhodopsin-like) of the $G$ protein-coupled receptor superfamily (GPCRs) responsible for signal transduction in cells. $G$ protein-coupled receptors have a similar structure, which includes seven transmembrane domains, three intracellular loops, three extracellular loops, and Cand N-terminal tails. Agonist binding to GPCR is the key for the initiation of signal transduction; hence, the receptor structure plays an important role in the regulation of many physiological cellular functions. Disturbances in agonist-receptor binding lead to signaling changes that can trigger pathological processes. An emerging topic of research involves cooperation between GPCRs that may be crucial for the regulation of cell functions (Bouvier, 2001; Ferre et al., 2014). The effectiveness of the agonist action on $G$ protein-coupled receptors depends on many factors, among which direct interactions between recep- tor molecules that form homodimers, heterodimers, or high-ordered oligomers can be distinguished (Thomsen et al., 2005; Milligan, 2009; Tadagaki et al., 2012). Different types of GPCR assembly have been proposed, including disulphide bond formation at the $\mathrm{N}$-terminal tails, coiled-coil interaction at the C-terminal tails, and direct interactions between transmembrane helices (Bouvier, 2001). The formation of GPCR oligomers has been widely demonstrated using different techniques, e.g., co-immunoprecipitation, bioluminescent resonance energy transfer, fluorescent resonance energy transfer, and proximity ligation assay (Thomsen et al., 2005). There is increasing evidence that the formation of GPCR dimers/oligomers is associated with a selective regulation of physiological processes through changes in signaling pathways (Milligan, 2009). Additionally, the association of the receptors may be helpful during biosynthesis and maturation of receptor proteins (Bulenger et al., 2005; Dupre \& Hebert, 2006).

GPCRs possess intracellular loops and C-terminal tails that may bind to several intracellular proteins named GPCR-interacting proteins. This group includes heterotrimeric $G$ proteins (with the $\alpha, \beta$ and $\gamma$ subunits), which initiate different signaling pathways, depending on the $\alpha$ subunit type $\left(\alpha_{\mathrm{s}}, \alpha_{\mathrm{i}}, \alpha_{\mathrm{q}}\right.$, and $\alpha_{12}$ subtypes). As a consequence, several secondary messengers such as cAMP, inositol phosphate, or $\mathrm{Ca}^{2+}$ are generated or, in opposite, their production is inhibited. The cellular responses triggered by these messengers include multiple physiological processes such as neurotransmission, cellular metabolism, secretion, cellular differentiation, cell growth, and immune responses (Agnati et al., 2003). In recent years, investigations of the interactions between GPCRs and

$\triangle$ e-mail: ibeth.guevara-lora@uj.edu.pl

*This topic was presented in part at the 43rd Winter School of the Faculty of Biochemistry, Biophysics and Biotechnology, 16-20 February 2016, Zakopane, Poland.

Abbreviations: $a_{10} R$; adrenergic receptor type $a_{1}$; $\beta_{1} R$, adrenergic receptor type $\beta_{1} ; A_{1} R$, adenosine receptor type $1 ; A_{2 A} R$, adenosine receptor type $2 A ; A C$, adenylate cyclase; Akt, protein kinase $B ; A T_{1} R$, angiotensin II receptor type 1; $A T_{2} R$, angiotensin II receptor type 2 ; $\mathrm{B} 1 \mathrm{R}$, bradykinin receptor type $1 ; \mathrm{B} 2 \mathrm{R}$, bradykinin receptor type 2 ; cAMP, cyclic adenosine monophosphate; CB1R, cannabinoid receptor type 1; D1R, dopamine receptor type 1; D2R, dopamine receptor type 2: D3R, dopamine receptor type 3; D4R, dopamine receptor type 4; D5R, dopamine receptor type 5; DAG, diacylglycerol; $E T_{B} R$, endothelin receptor type $B ;$ Gal $R$, galanin receptor type 1 ; GPCRs, G protein-coupled receptors; GIRK, G protein-gated inwardly rectifying potassium channel; GRKs, G protein-coupled receptor kinases; GSK-3, glycogen synthase kinase $3 ; 5 \mathrm{HT}_{2 \mathrm{~A}} \mathrm{R}$, serotonin $2 \mathrm{~A}$ receptor; $\mathrm{H}_{3} \mathrm{R}$, histamine receptor type $3 ; \mathrm{IP}_{3}$, inositol triphosphate; MAPK, mitogen-activated protein kinases; NMDAR, NMDA receptor; NST1R, neurotensin receptor type 1; PI3K, phosphoinositide 3 kinase; PKA, protein kinase A; PKC, protein kinase C; PLC, phospholipase C; SST5R, somatostatin receptor type 5; TAAR1, trace amineassociated receptor type 1. 
$\beta$-arrestin have been focused not only on processes related to the cellular trafficking machinery of receptors but also on the function of $\beta$-arrestin as an adaptor molecule that can regulate the receptor signaling (Shenoy \& Lefkowitz, 2011). The mechanism of the interactions between $\beta$-arrestin and the receptor is biphasic, including a first phase of loose binding of $\beta$-arrestin to the phosphorylated C-terminal tail of GPCR, followed by the docking of this protein to the receptor core (Ghosh et al., 2015). Hence, interactions with kinases (GRKs) for GPCR phosphorylation are also expected. In fact, such interactions lead to increased kinase activity (Maurice et al., 2011). It has been suggested that one GRK molecule can successfully phosphorylate both receptors in an oligomer complex. Moreover, relevant changes in signaling of at least one of the receptors that form this heteromultimer can take place after assembling the macromolecular complex on cell membranes. The activation of one of the participating receptors by its agonist may allosterically suppress or promote the activation of the second receptor and may induce conformational changes in the receptors, leading to the activation of different signaling pathways (Smith \& Milligan, 2010; Ferre et al., 2014).

Recently, cooperation of both kinin receptors and dopamine receptors with other GPCRs, which modulates their functions, has been demonstrated. Since these receptors are ubiquitously expressed in many tissues, direct cooperation between them, which may result in the regulation of crucial cellular processes, seems to be possible. Therefore, in this review, we present the most recent facts related to protein-protein interaction with concomitant signaling changes for these two classes of receptors, which, taken together, strongly support the hypothesis of effective and functional cooperation between kinin and dopamine receptors.

\section{DOPAMINE RECEPTORS - CHARACTERISTICS AND SIGNALING}

Dopamine, a catecholaminergic neurotransmitter, is an important modulator of diverse functions of the central nervous system such as locomotion, cognition, emotion, positive reinforcement, food intake, and endocrine regulation (Vallone et al., 2000; Beaulieu \& Gainetdinov, 2005; Hisahara \& Shimohama, 2011). This compound also regulates a variety of functions regarding, among others, the cardiovascular system, hormone secretion, and the renal and gastrointestinal system (Missale et al., 1998). Dopamine acts through specific receptors belonging to the GPCRs family. Two groups of dopamine receptors have been distinguished, both widely distributed in human tissues. The D1-like family comprises the receptor types D1 (D1R) and D5 (D5R) and the D2like family contains the receptor types D2, D3, and D4 (D2R, D3R and D4R, respectively) (Missale et al., 1998; Vallone et al., 2000). The classification of dopamine receptors is based on their ability to stimulate an intracellular cAMP increase (D1-type receptors) or to downregulate cAMP production due to adenylate cyclase (AC) inhibition (D2-type receptors).

Although dopaminergic receptors possess a similar primary amino acid sequence and a common structure, their functions depend mainly on $G$ protein activation (Fig. 1). Different $G$ proteins can trigger different signaling pathways; however, $G$ protein-independent signaling has also been demonstrated (Beaulieu et al., 2015).

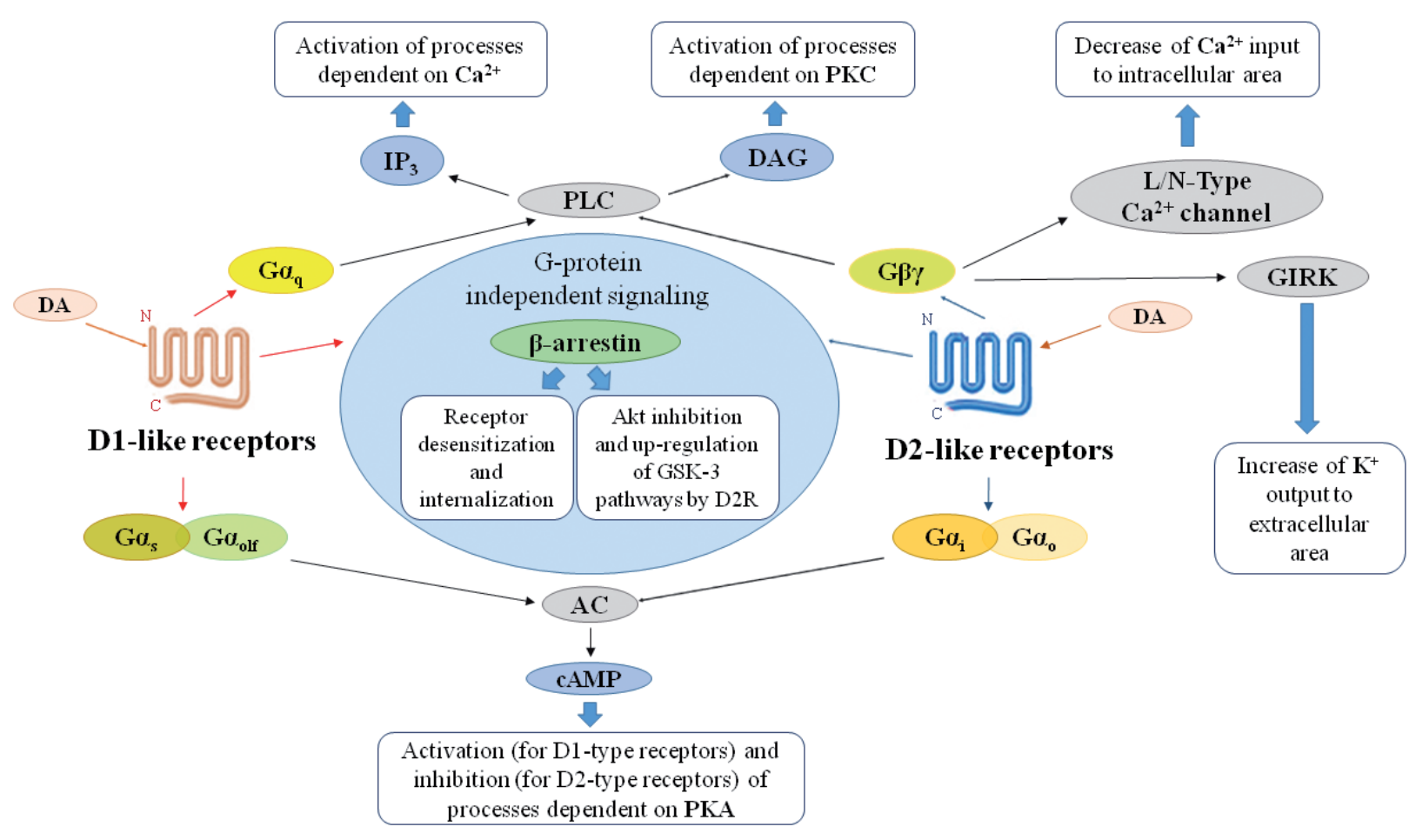

Figure 1. Signaling of dopamine receptors.

Dopamine receptors regulate a variety of processes dependent on calcium ions, PKA, and PKC through G proteins or by G protein-independent mechanisms. The figure was prepared on the basis of the information contained in articles cited in the text. AC, adenylate cyclase; DA, dopamine; DAG, diacylglycerol; GIRK, G protein-gated inwardly rectifying potassium channel; GSK-3, glycogen synthase kinase 3; IP ${ }_{3}$ inositol triphosphate; PKA, protein kinase A; PKC, protein kinase C; PLC, phospholipase C. 
In fact, the main signaling pathway that has served to differentiate these receptors is related to AC activation, which, in turn, regulates the intracellular cAMP level. The D1 receptor, through a $\mathrm{G} \alpha_{\mathrm{s} / \mathrm{olf}}$ protein, activates AC with the release of cAMP while an inhibitory effect is exerted by D2-like receptors through $G \alpha_{i / o}$ proteins, causing a decrease in the cAMP concentration. cAMP is an important secondary messenger that activates protein kinase A (PKA) which, in turn, phosphorylates numerous cytosolic and nuclear substrates, regulating diverse cellular functions (Sassone-Corsi, 2012). Therefore, a crosstalk between dopaminergic receptors and other GPCRs on the signaling pathways may be expected through the activation of some proteins by this kinase. For example, the $32 \mathrm{kDa}$ dopamine- and cAMP-regulated phosphoprotein is activated by PKA and may function as a regulator of signal transduction of other

GPCRs (Greengard, 2001; Beaulieu et al., 2015; Polito et al., 2015).

On the other hand, the D1-like receptors can act through $\mathrm{G} \alpha_{\mathrm{q}}$ promoting cAMP-independent cell signaling. In this case, phospholipase $\mathrm{C}$ is directly activated by the $G$ protein with subsequent production of inositol triphosphate $\left(\mathrm{IP}_{3}\right)$ and diacylglycerol (DAG). The first product leads to increased mobilization of intracellular $\mathrm{Ca}^{2+}$, while DAG activates protein kinase C (PKC). A similar effect is observed after activation of the D2like receptor by dopamine. However, the $\beta / \gamma$ subunits of the $G$ protein are involved in this signaling. In addition, intracellular $\mathrm{Ca}^{2+}$ and $\mathrm{K}^{+}$levels may be modulated by $\mathrm{D} 2$-like receptors through the $\beta / \gamma$ subunit, leading to inactivation of the $\mathrm{L} / \mathrm{N}$ calcium channels and activation of the $G$ protein-coupled inwardly rectifying potassium channels (GIRK) (Yan et al., 1997; Lavine et al., 2002).

Other $G$ protein-independent signaling routes of dopamine receptors have also been elucidated (Beaulieu et al., 2015) (Fig. 1). The dopamine receptors are able to interact directly with $\mathrm{L} / \mathrm{N}$ type $\mathrm{Ca}^{2+}$ channels and ionotropic channels such as glutamate and GABA receptors, thus modulating their functions (Zamponi \& Currie, 2013; Li et al., 2014). In addition, molecules responsible for receptor phosphorylation and desensitization, such as GRKs and $\beta$-arrestins, may mediate the dopamine functions through the $G$ protein-independent pathways of dopamine receptors (Tiberi et al., 1996; Kim et al., 2001; Del'Guidice et al., 2011; Peterson et al., 2015). The involvement of dopamine receptors through $\beta$-arrestin in the regulation of signaling pathways of several kinases, e.g. protein kinase B (Akt) and glycogen synthase kinase 3 (GSK-3), has been reported. The D2R/ $\beta$-arrestin 2 interaction is followed by binding of Akt with protein phosphatase 2, causing Akt inactivation (Del'Guidice et al., 2011; Beaulieu et al., 2015). Since GSK-3 is inhibited by Akt, its inactivation implicates up-regulation of this pathway (Urs et al., 2012; Beaulieu et al., 2015).

It should also be mentioned that the signaling of dopamine receptors can be regulated through the modulation of $G$ protein activity. There is a group of proteins that act as regulators of signal transduction of GPCRs (Taymans et al., 2003; Anderson et al., 2010).

\section{FUNCTIONAL DOPAMINE RECEPTOR OLIGOMERS WITH OTHER GPCRS}

The regulation of intracellular signaling by GPCRs is multi-faceted and sophisticated. There is a large body of evidence that collaboration between GPCRs may alter the function of these receptors (Agnati et al., 2003; Beau- lieu \& Gainetdinov, 2005; Prinster et al., 2005; Milligan, 2013; Perrault et al., 2014; Beaulieu et al., 2015). The formation of receptor dimers, both homodimers and heterodimers, has been associated with significant changes in cell functions. For example, the homodimerization of D2R may induce allosteric modulation of the signaling of those receptors (Han et al., 2009). The formation of heterodimers by dopamine receptors has widely been reported (Table 1). Moreover, direct interactions between D1 and D2 receptors have been observed (Lee at al., 2004; Dziedzicka-Wasylewska et al., 2006; Lukasiewicz et al., 2009). Even though the influence of this dimer on PLC-mediated signaling is not satisfactorily studied, its significance in the regulation of diverse mental disorders, such as schizophrenia, attention-deficit hyperactivity disorder, and addiction has been shown (Perreault et al., 2014a). Interactions between D1R and D3R (Zeng et al., 2004; Marcellino et al., 2008) have also been reported. The D1R/D3R dimer formation results in an additive vasorelaxant effect in rat mesenteric artery, caused by the stimulation of $\mathrm{K}^{+}$channels. In addition, the intramembrane $\mathrm{D} 1 \mathrm{R} / \mathrm{D} 3 \mathrm{R}$ interaction potentiated D1Rmediated behavioral effects in mice stimulated with D3R agonists. In turn, the D2R/D5R dimer formation has been demonstrated in HEK transfected cells (O'Dowd et al., 2013). This heterodimer attenuates extensive calcium mobilization stimulated by D3 agonists (So et al., 2009). Furthermore, co-localization between D2-like receptors, such as D2R/D3R (Scarselli et al., 2001; Pou et al., 2012) and D2R/D4R (Borroto-Escuela et al., 2011; Gonzalez et al., 2012a;) has also been established.

A high number of heterodimers of dopamine receptors with other GPCRs causing changes in the functions of separate receptors have been reported (Table 1). In this context, the D1R and D2R can interact with adenosine receptors $\left(A_{1} R\right.$ and $\left.A_{2} R\right)$ and form $D 1 R-A_{1} R$ (Gines et al., 2000; Toda et al., 2003) and D2R-A $\mathrm{R}$ dimers (Canals et al., 2003; Borroto-Escuela et al., 2016). The formation of these heteromers causes changes in $G$ protein signaling of dopamine receptors associated with the AC/PKA pathway, especially after co-activation with agonists. Heterodimers of adrenergic receptor subtypes $\alpha_{1 \mathrm{~B}}\left(\alpha_{1 \mathrm{~B}} \mathrm{R}\right)$ and $\beta_{1}\left(\beta_{1} \mathrm{R}\right)$ with $\mathrm{D} 4 \mathrm{R}$ have also been proposed, demonstrating regulation of melanin synthesis and release in rat pineal gland (Gonzalez et al., 2012b). The formation of these heteromers results in inhibition of adrenergic receptor signaling by dopamine alongside with blocking serotonin and melatonin synthesis induced by adrenergic receptor ligands. Furthermore, the arrangement of several dimers of angiotensin II receptor types 1 and 2 (AT $\mathrm{R}$ and $\mathrm{AT}_{2} \mathrm{R}$, respectively) and dopamine receptors has been shown. The $\mathrm{AT}_{1}$ receptor formed heterodimers with $\mathrm{D} 1 \mathrm{R}$ in immortalized renal proximal tubule cells from Wistar-Kyoto rats and spontaneous hypertensive rats (Zeng et al., 2005b). In the first case, angiotensin II regulated positively the D1R expression but no effect was observed in the cells from hypertensive rats. In turn, formation of a $\mathrm{D} 2 \mathrm{R}-\mathrm{AT}_{1} \mathrm{R}$ heterodimer was observed in co-transfected HEK-293T cells, showing that this interaction did not affect the D2R-induced cAMP signaling but could attenuate $\mathrm{AT}_{1} \mathrm{R}$ coupling to Gq (Martinez-Pinilla et al., 2015). The D3R receptor colocalizes with $\mathrm{AT}_{1} \mathrm{R}$ in immortalized renal proximal tubule cells from rats leading to decreased $\mathrm{AT}_{1} \mathrm{R}$ expression by D3R agonist (Zeng et al., 2006). On the other hand, the $\mathrm{D} 5 \mathrm{R}-\mathrm{AT} \mathrm{T}_{1} \mathrm{R}$ formation can negatively regulate the expression of any other receptor by agonists (Zeng et al., 2005a). The second angiotensin receptor, $\mathrm{AT}_{2} \mathrm{R}$, can interact with D1R and cooperatively increase the 
Table 1. Heterodimers of dopamine receptors and their functional relevance.

\begin{tabular}{|c|c|c|}
\hline Dimer & Changes in cell signaling or receptor functions & References \\
\hline D1R-D2R & Co-activation induces enhanced $\mathrm{Ca}^{2+}$ release; GSK-3 $\beta$ inactivation & $\begin{array}{l}\text { Lee et al., 2004; Perrault et al., } \\
2014\end{array}$ \\
\hline D1R-D3R & $\begin{array}{l}\text { Vasorelaxant effect in rat mesenteric artery; D3 agonists potentiate D1-media- } \\
\text { ted mice locomotor activity }\end{array}$ & $\begin{array}{l}\text { Zeng et al., 2004; Marcellino et al., } \\
2008\end{array}$ \\
\hline D2R-D3R & $\mathrm{D} 2 \mathrm{R}$ receptor rescues the ability of $\mathrm{D} 3 \mathrm{R}$ to inhibit $\mathrm{AC}-\mathrm{VI}$ & Scarcelli et al., 2001 \\
\hline D2R-D4R & D2R potentiates D4R-mediated inhibition of glutamate release & Gonzalez et al., 2012a \\
\hline D2R-D5R & Attenuation of $\mathrm{Ca}^{2+}$ signaling mediated by D5R & So et al., 2009 \\
\hline D1R-A ${ }_{1} R$ & $\begin{array}{l}\text { Co-activation decreases the D1R-induced accumulation of cAMP and leads to } \\
\text { uncoupling of D1R from G protein }\end{array}$ & Gines et al., 2000; Toda et al., 2003 \\
\hline$D 2 R-A_{2 A} R$ & $\begin{array}{l}A_{2 A} R \text { agonists inhibit D2R Ga } a_{i / 0}-\text { mediated signaling and D2R } \beta \text {-arrestin-mediated } \\
\text { signaling }\end{array}$ & Borroto-Escuela et al., 2016 \\
\hline D4R- $a_{1 B} R$ & Dopamine inhibits adrenergic receptor signaling & Gonzalez et al., 2012b \\
\hline$D 4 R-\beta_{1} R$ & Dopamine inhibits adrenergic receptor signaling & Gonzalez et al., 2012b \\
\hline D1R-AT ${ }_{1} R$ & $\mathrm{AT}_{1} \mathrm{R}$ agonist regulates positively the D1R expression & Zheng et al., 2005b \\
\hline $\mathrm{D} 2 \mathrm{R}-\mathrm{AT}{ }_{1} \mathrm{R}$ & Allosteric interaction between the heteromers a G protein complex & Martinez-Pinilla et al., 2015 \\
\hline D3R- $A T_{1} R$ & D3R agonist regulates $A T_{1} R$ expression & Zeng et al., 2006 \\
\hline D5R- $A T_{1} R$ & $\begin{array}{l}\text { Activation of D5 and AT1 receptors negatively regulates the expression of each } \\
\text { other }\end{array}$ & Zeng et al., 2005a \\
\hline $\mathrm{D} 1 \mathrm{R}-\mathrm{AT}_{2} \mathrm{R}$ & Increased CAMP and cGMP production, $\mathrm{Na}^{+}$transport inhibition & Gildea et al., 2012 \\
\hline D2R-CB1R & Potentiation of AC inhibition after co-stimulation & Kearn et al., 2005 \\
\hline $\mathrm{D} 3-\mathrm{ET}_{\mathrm{B}} \mathrm{R}$ & $\begin{array}{l}\text { D3 agonist enhances } \mathrm{ET}_{\mathrm{B}} \mathrm{R} \text { expression by a calcium channel-mediated mecha- } \\
\text { nism }\end{array}$ & Yu et al., 2009 \\
\hline D1R-Gal $R$ & Modulation of the cholinergic neurotransmission in hippocampus & Moreno et al., 2011a \\
\hline $\mathrm{D} 1 \mathrm{R}-\mathrm{H}_{3} \mathrm{R}$ & $\begin{array}{l}\text { Receptor antagonists lead to conformational changes in each receptor with } \\
\text { blocking of original dimer signaling }\end{array}$ & $\begin{array}{l}\text { Ferrada et al., 2009; Moreno et al., } \\
\text { 2011b }\end{array}$ \\
\hline $\mathrm{D} 2 \mathrm{R}-\mathrm{H}_{3} \mathrm{R}$ & $\mathrm{H}_{3} \mathrm{R}$ agonists decrease the D2R affinity for specific agonists & Ferrada et al., 2008 \\
\hline D1R-NMDAR & $\begin{array}{l}\text { D1R agonist regulates NMDAR-mediated functions by a PI3K-dependent mecha- } \\
\text { nism }\end{array}$ & Lee et al., 2002; Nai et al., 2010 \\
\hline D2R-NMDAR & $\begin{array}{l}\text { Disruption of the association of } \mathrm{Ca}^{2+} / \mathrm{calmodulin} \text {-dependent protein kinase II } \\
\text { with the NR2B subunit with reduction of NMDAR signaling }\end{array}$ & Liu et al., 2006 \\
\hline D2R-NST1R & NST1R agonists inhibit the D2R-mediated AC/PKA pathway & Borroto-Escuela et al., 2016 \\
\hline $\mathrm{D} 2 \mathrm{R}-5 \mathrm{HT} \mathrm{T}_{2 \mathrm{~A}} \mathrm{R}$ & $\begin{array}{l}5 \mathrm{HT}_{2 \mathrm{~A}} \mathrm{R} \text { activation by an endogenous agonist attenuates the D2R-dependent } \\
\mathrm{AC} / \mathrm{PKA} \text { pathway release }\end{array}$ & Borroto-Escuela et al., 2010 \\
\hline D2R-SST5R & SST5R agonist and D2R agonist enhance the inhibition of CAMP release & Rocheville et al., 2000 \\
\hline D2R-TAAR1 & D2R agonists enhance the TAAR1-mediated cAMP release & Espinoza et al., 2011 \\
\hline
\end{tabular}

cAMP and cGTP production with $\mathrm{Ca}^{2+}$ transport inhibition (Gildea et al., 2012). Additionally, a crosstalk between D2R and a cannabinoid receptor (CB1R) has been reported, demonstrating physical interactions between these receptors (Kearn et al., 2005). Co-activation of D2R-CB1R results in initiation of a cAMP-dependent signaling cascade distinct from those of the participant receptors, with changes in neurotransmission. Another heterodimer of dopamine receptors with GPCRs is involved in the interaction of D3R with endothelin receptor type $\mathrm{B}\left(\mathrm{ET}_{\mathrm{B}} \mathrm{R}\right)$. The formation of this dimer was observed in renal proximal tubule cells of Wistar-Kyoto and hypertensive rats, showing significant importance for hypertension regulation ( $\mathrm{Yu}$ et al., 2009). A different heterodimer established, generated from D2R and galanin receptor $1\left(\mathrm{Gal}_{1} \mathrm{R}\right)$, modulates cholinergic neurotransmission in the rat ventral hippocampus (Moreno et al., 2011a). Other GPCRs that are able to dimerize with dopamine receptors are histamine $\mathrm{H}_{3}$ receptors. The D1 $\mathrm{R}-\mathrm{H}_{3} \mathrm{R}$ dimer formation induces a different crosstalk of the participating receptors, which is associated with protein conformational changes upon activation of the partner receptor causing subsequent changes in receptor signaling (Ferrada et al., 2009; Moreno et al., 2011b). In turn, the generation of the D2R- $\mathrm{H}_{3} \mathrm{R}$ dimer causes an $\mathrm{H}_{3} \mathrm{R}$ agonist-mediated diminution of $\mathrm{D} 2 \mathrm{R}$ affinity for the agonist (Ferrada et al., 2008). The interaction of the N-methyl-D-aspartate receptor (NMDAR) with D1R (Lee et al., 2002; Nai et al., 2010) and D2R (Liu et al.,
2006) has also been documented. The carboxyl tail of the D1 receptor can directly and selectively interact with NMDA glutamate receptor subunits and the formation of the dimer results in inhibition or attenuation of the NMDA receptor-mediated excitotoxicity depending on subunit interaction. In turn, a direct and dynamic D2RNR2B subunit interaction in striatal neurons reduces the NMDAR signaling. Moreover, a heterocomplex involving D2R, NMDAR, and metabotropic glutamate receptor 5 has recently been proposed as an intermediate complex (Borroto-Escuela et al., 2016). Another heterodimer that regulates cellular signaling is formed between D2R and neurotensin receptor type 1 (NTS1R) (Borroto-Escuela et al., 2016). NTS1R agonists induce D2 inhibition of the AC-PKA-CREB pathway. Physical interactions between $\mathrm{D} 2 \mathrm{R}$ and the serotonin $5 \mathrm{HT}_{2 \mathrm{~A}}$ receptor $\left(5 \mathrm{HT}_{2 \mathrm{~A}} \mathrm{R}\right)$ have been reported (Borroto-Escuela et al., 2010; Lukasiewicz et al., 2010). Serotonin, the endogenous ligand of 5-HT2A, exerts an allosteric antagonistic action on D2R signaling in the 5-HT2A-D2R complex. In contrast, hallucinogenic agonists lead to potentiation of Gi/o signaling of the D2R, producing an enhanced inhibition of the AC-PKA pathway in these heteroreceptor complexes (Borroto-Escuela et al., 2016). Although so far there have been no studies on the coupling of the serotonin $5 \mathrm{HT}_{2 \mathrm{~A}}$ receptor with $\mathrm{D} 1 \mathrm{R}$, a D1R-mediated effect on pyramidal neuron plasticity induced by agonists of serotonin receptor has been reported (Meunier et al., 2015). The established interaction between D2R and somatosta- 
tin receptor subtype 5 (SST5R) enhances the functional activity of SSTR5R after dopamine stimulation or the D2R-mediated AC inhibition by SST5R agonists (Rocheville et al., 2000). Other cooperation of dopamine receptors includes the interaction between D2R and trace amine associated receptor 1 (TAAR1) that is crucial for the modulation of the dopaminergic system by TAAR1 (Espinoza et al., 2011; Leo et al., 2014).

Significant implications for the modulation of cell signaling through a majority of these complexes have been described. However, the possibility that dopamine receptors may interact with other GPCRs forming new dimers is feasible. For example, kinin receptors, which are widely spread in tissues and responsible for numerous physiological functions, may be regarded as potential partners for a crosstalk with dopamine receptors. Hereunder we describe their structural and functional characteristics in order to find convergence of signaling pathways.

\section{KININ RECEPTORS - CHARACTERISTICS AND SIGNALING}

Another group of $G$ protein-coupled receptors, on which the current review is focused, includes kinin receptors. Kinins are well known pro-inflammatory peptides dynamically produced and degraded under physiological conditions at the vessel wall and at sites of local infection or injury (Joseph \& Kaplan, 2005; GuevaraLora et al., 2011; Guevara-Lora et al., 2013). The most important representatives of this group are bradykinin and kallidin (Lys-bradykinin), which can be specifically degraded by carboxypeptidases to form des-Arg-kinins - des-Arg-bradykinin (DABK) and des-Arg ${ }^{10}$-kallidin (DAKD), respectively. These peptides, although modified, retain their biological activity (Blais et al., 2000; Leeb-Lunderg et al., 2005). Kinins have protective effects on the circulatory system, determining its homeostasis, and on the electrolyte and glucose transport, but there is also evidence for the participation of these peptides and their metabolites in different disorders associated with chronic inflammatory responses such as those associated with cardiovascular and renal diseases, diabetes, cancer, chronic pain, and neurodegeneration (Marceau et al., 2002; Leeb-Lunderg et al., 2005; Moreau et al., 2005; Figueroa et al., 2012; Guevara-Lora, 2012). Kinins and their metabolites without the $\mathrm{C}$-terminal arginine residue are recognized by two types of receptors, the bradykinin receptor type $1(\mathrm{~B} 1 \mathrm{R})$ and type $2(\mathrm{~B} 2 \mathrm{R})$. B1R preferably binds des-Arg peptides, while B2R primarily recognizes bradykinin and kallidin. B2R is ubiquitously present on numerous cells, while the B1R expression in cell membranes is mainly induced by certain stimuli.

Kinin receptors act through the $G$ proteins, activating similar pathways (Fig. 2). The main $G$ protein subtype involved in their signaling is $\mathrm{G} \alpha_{\mathrm{q}}$, which initiates a signal transduction cascade through phospholipase C (PLC), leading to $\mathrm{IP}_{3}$ hydrolysis and DAG generation. Further reactions imply an increase in intracellular $\mathrm{Ca}^{2+}$ and $\mathrm{PKC}$ activation (Blaukat, 2003; Leeb-Lundberg et al., 2005; Marceau et al., 2013). Nitric oxide synthase induction with subsequent nitric oxide production is stimulated via $\mathrm{G} \alpha_{\mathrm{q}}$ through $\mathrm{Ca}^{2+}$-dependent mechanisms in endothelial cells. Prostaglandin release is also mediated by $\mathrm{Ca}^{2+}$, which activates cytosolic phospholipase $A_{2}$. In turn,

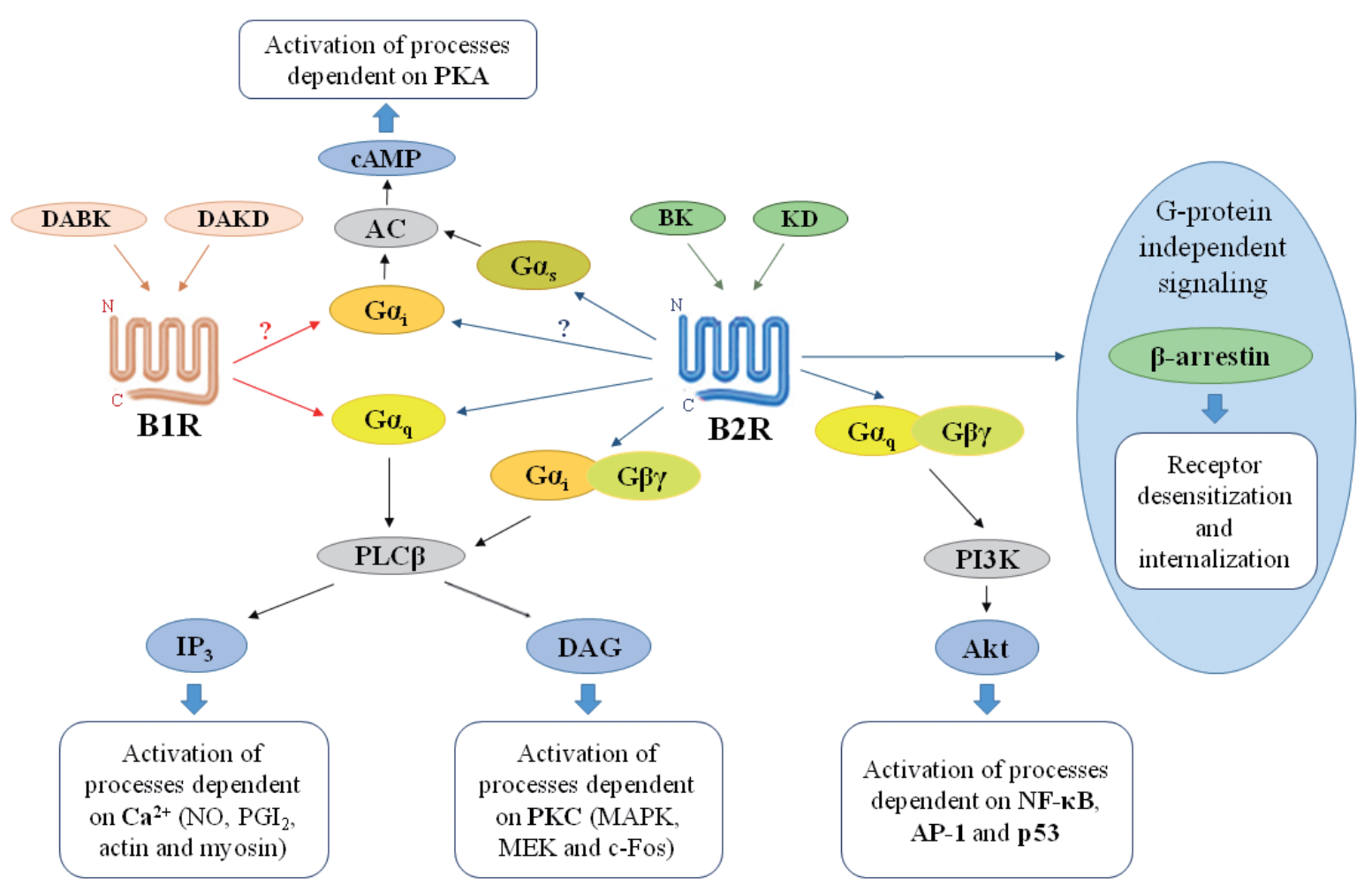

Figure 2. Signaling of kinin receptors.

The activation of several cellular processes is mediated by B1R and B2R through different G protein subunits and the $\beta$-arrestin protein. The outline of the signaling of kinin receptors was prepared on the basis of the information contained in articles cited in the text. AC, adenylate cyclase; Akt, protein kinase B; AP-1, activator protein 1; B1R, bradykinin receptor type 1; B2R, bradykinin receptor type 2; BK, bradykinin; DABK, des-Arg9-bradykinin; DAG, diacylglycerol; DAKD, des-Arg'10-kallidin; IP ${ }_{3}$, inositol triphosphate; KD, kallidin; MAPK, mitogen-activated protein kinases; MEK, MAPK kinase; NF- $\kappa \mathrm{B}$, nuclear factor kappa-light-chain-enhancer of activated B cells; PI3K, phosphoinositide 3 kinase; G I $_{2}$, prostacyclin $I_{2}$; PKA, protein kinase A; PKC, protein kinase C; PLC, phospholipase C. 
Table 2. Dimerization of kinin receptors and their documented functional relevance.

\begin{tabular}{|c|c|c|}
\hline Dimer & Changes in cell signaling or receptor functions & References \\
\hline B1R-B1R & $\begin{array}{l}\text { Receptor trafficking and maturation; essential for the presentation of the } \\
\text { receptor in the membrane }\end{array}$ & $\begin{array}{l}\text { Kang et al., 2005; Sanden \& } \\
\text { Leeb-Lundberg, } 2013\end{array}$ \\
\hline B1R-B2R & $\begin{array}{l}\text { Regulation of PLC } \beta \text { activation; B2R proteolysis by B1R stimulation with ago- } \\
\text { nist; regulation of B1R expression on membrane by B2R agonist }\end{array}$ & $\begin{array}{l}\text { Barki-Harrington et al., 2003; } \\
\text { Kang et al., 2004; Enquist et al., } \\
\text { 2014; Zhang et al., } 2015\end{array}$ \\
\hline B2R-B2R & Regulation of receptor internalization; receptor-mediated signal attenuation & AbdAlla et al., 1999 \\
\hline $\mathrm{B} 2 \mathrm{R}-\mathrm{AT} \mathrm{T}_{1} \mathrm{R}$ & AT 1 R-stimulated increase in $\mathrm{G}$ protein activation & AbdAlla et al., 2000 \\
\hline $\mathrm{B} 2 \mathrm{R}-\mathrm{AT}_{2} \mathrm{R}$ & Enhanced production of NO and cGMP & Abadir et al., 2006 \\
\hline B1R-apelin receptor & $\begin{array}{l}\text { Co-stimulation enhances activity of PKC signaling pathways, increases } \mathrm{Ca}^{2+} \\
\text { release and promotes eNOS phosphorylation }\end{array}$ & Bai et al., 2014 \\
\hline
\end{tabular}

DAG recruits $\mathrm{PKC}$, promoting tyrosine phosphorylation in mitogen-activated protein kinases (MAPK). Another signaling by bradykinin is associated with phospholipase $\mathrm{D}$ activation, which is mediated by $\mathrm{Ca}^{2+}$ influx and PKC.

Besides the $G \alpha_{\mathrm{q}}$ subunit, kinin receptors may also transmit a signal through other $G$ proteins. The B1R coupling to $\mathrm{G} \alpha_{\mathrm{q}}$ and $\mathrm{G} \alpha_{\mathrm{i}}$ was demonstrated by immunoprecipitation (Austin et al., 1997). Additional B2R interactions with the $G \beta \gamma$ and $G \alpha_{i}$ subunits, activating PLC, have been observed (Camps et al., 1992; Philip et al., 2007). An interaction between $B 2 R$ and the $G \alpha_{q}$ and G $\beta \gamma$ subunits, which mediates the activation of several transcription factors such as NF- $\mathrm{KB}$ and AP-1 by bradykinin through PI3K/Akt pathways, has been suggested (Xie et al., 2000; Zhu et al., 2003). Since both kinin receptors are involved in similar signaling pathways, their desensitization with subsequent internalization could be the critical factor in inferring the contribution of these receptors (Prado et al., 2002; Leeb-Lunderg et al., 2005). $\mathrm{B} 2 \mathrm{R}$ is constitutively expressed in cell membrane but after kinin stimulation can desensitize with subsequent internalization and resensitization. The phosphorylation of the B2R C-terminal domain is necessary for receptor densensitization and internalization. The desensitization is regulated through interactions of the phosphorylated receptor with $\beta$-arrestin (Marceau et al., 2013). B1R cannot internalize completely in response to agonists, partly because of the absence of phosphorylation sites in the C-terminal domain. The slow and extended cellular response of this receptor is attributed to its inability to internalize (Enquist et al., 2014). Therefore, the divergence between B1R and B2R signaling is associated with desensitization mechanisms.

\section{FUNCTIONAL RELEVANCE OF KININ RECEPTOR COUPLING}

As in the case of other GPCRs, kinin receptors can also interact with other proteins directly in membranes. Besides interactions with proteins involved in kinin generation, such as some membrane enzymes, interactions of these receptors with other GPCRs comprising homodimers and heterodimers have been proven (Table 2). So far, the most extensively studied area encompasses homodimerization of $\mathrm{B} 1 \mathrm{R}$ and $\mathrm{B} 2 \mathrm{R}$. The first report showing B2R dimerization with attenuated receptor-mediated signalization was published at the end of the nineties (AbdAlla et al., 1999). The report provided evidence for a significant role of the N-terminal domain of B2R for the agonist-induced receptor dimerization. Furthermore, post-translation modifications such as N-glycosylation, sialylation, and disulphide bonding seem to be crucial for B2R dimerization (Michineau et al., 2006). B1R can also occur in membranes in the homodimer form. Physical interactions between these receptors, substantial for their adequate functions, have been reported (Kang et al., 2005). Recently, it has been shown that the formation of B1R dimers may already take place at the stage of protein translation and maturation (Sanden \& LeebLundberg, 2013). The authors proved that the dimerization was required for the trafficking of the B1 receptor. In addition, it was shown that some fragments of transmembrane helices $1,2,3$, and 4 seemed to be of vital importance for the interaction.

At the same time, the interest in the studies on the formation of heterodimers by kinin receptors has been growing. The heterologous B1R-B2R interaction was demonstrated for the first time in membranes of prostate cancer PC3 cells (Barki-Harrington et al., 2003). In this report, it was demonstrated that the antagonist of one of the receptors interferes with the signaling ability of the other, through $\mathrm{G} \alpha_{\mathrm{q}}$ mediation. It was suggested that the dimer may control the proliferation of cancer cells through PLC $\beta$ signaling. In addition, cells co-expressed with B1R and B2R showed spontaneous heterodimerization, which promoted hydrolytic degradation of B2R (Kang et al., 2004). The authors suggested that this proteolytic plasma membrane mechanism is necessary to remove B2R since this receptor quickly recycles and may be down-regulated after prolonged agonist stimulation. Therefore, this effect can partially explain the sustained signalization of B1 receptors during uncontrolled inflammatory response. Moreover, a recent report also suggests that dimerization between $\mathrm{B} 1 \mathrm{R}$ and $\mathrm{B} 2 \mathrm{R}$ can be a regulating factor for the prolonged expression of $\mathrm{B} 1 \mathrm{R}$ in membranes (Enquist et al., 2014). In addition, a more recent report suggested down-regulation of B1R responses by the $\mathrm{B} 2 \mathrm{R}$ agonist that is associated with co-endocytosis of the B1R-B2R dimer (Zhang et al., 2015). The suggestions that B1R-B2R interactions may be involved in the regulation of receptor expression mediated by the agonist of the partner receptor agree with previous reports, indicating autoregulation between B1R and B2R (Phagoo et al., 1999; Guevara-Lora et al., 2009).

The first report concerning the heterodimerization of the kinin receptor with other GPCRs appeared already at the beginning of this century. The dimerization of the angiotensin II type 1 receptor $\left(\mathrm{AT}_{1} \mathrm{R}\right)$ with $\mathrm{B} 2 \mathrm{R}$, with alteration of receptor sequestration was established (AbdAlla et al., 2000). In that study, enhanced angiotensin signaling through $G \alpha$ without a bradykinin effect was interpreted in terms of dimer formation. Moreover, the physical interaction between these receptors was also confirmed by confocal FRET imaging (Quitterer et al., 2011). It was suggested that the mechanisms of coupled receptor endocytosis significantly differ from those of 
monomers. Functional implications of the B2R-AT $R$ dimerization related to their contribution to angiotensin II hyperresponsiveness of mesangial cells were also observed in an experimental model of hypertension (AbdAlla et al., 2005). A second, functional dimer of B2R with angiotensin II type 2 receptor in PC12V cell membranes was reported (Abadir et al., 2006). The physical interaction between these receptors initiates changes in intracellular phosphoprotein signaling activities enhancing production of $\mathrm{NO}$ and cGMP. A recent study has shown the formation of a B1R dimer with an apelin receptor involved in homeostasis regulation (Bai et al., 2014). The interaction between these receptors leads to enhanced eNOS phosphorylation and PKC signaling pathways, increasing $\mathrm{NO}$ and $\mathrm{Ca}^{2+}$ release.

As described above, the phenomenon of dimerization occurs in a majority of GPCRs, including the subclasses of kinin and dopaminergic receptors. Therefore, it would be valuable to check out possible interactions between these receptors, which could indicate changes in their functions.

\section{CONVERGENCE OF SIGNALING PATHWAYS OF KININ AND DOPAMINE RECEPTORS}

The fact that kinin and dopamine receptors, due to their nature, act mainly through $G$ proteins implies possible competition between receptors for the binding to these proteins. As mentioned above, the main subclasses of $G$ proteins for dopaminergic receptors are $G \alpha_{s}, G \alpha_{i}$, and $G \alpha_{0}$ which transmit signals through the cAMP pathways (Fig. 1). On the other hand, B1R- and B2R-mediated alteration in cAMP may occur (Fig. 2) (Zhang et al., 2009; Ben-Shmuel et al., 2013). Several indirect pathways, including those activated by $G \alpha_{s}$ and $G \alpha_{i}$ subunits have been proposed. Therefore, simultaneous stimulation of kinin and dopamine receptors may alter cAMP signaling pathways. Indeed, a crosstalk between dopaminergic receptors and $\mathrm{B} 1 \mathrm{R}$ has been demonstrated (De Brito Gariepy et al., 2010). A significant contribution of the $\mathrm{D} 2$ receptor in the antihypertensive effect of $\mathrm{B} 1 \mathrm{R}$ antagonists has recently been reported, suggesting that upregulated brain $\mathrm{B} 1 \mathrm{R}$ could contribute to the regulation of arterial hypertension through the dopamine system.

The $G \alpha_{\text {, }}$ subunit seems to be a good partner for mediation of interactions between kinin and dopaminergic receptors, which may induce effective cross-talking between these receptors. Both kinin receptors and D1-like receptors transduce signals through this pathway with the activation of PLC $\beta$, leading to increased release of calcium ions and DAG production. Recently, enhanced B1R expression in rat vascular smooth muscle cells induced by angiotensin II has been demonstrated. This effect, which was attributed to activation of MAPK pathways, was mediated by an $\mathrm{AT}_{1}$ receptor and an endothelin type A receptor $\left(\mathrm{ET}_{\mathrm{A}} \mathrm{R}\right)$ (Morand-Contant et al., 2010). Since direct interactions between dopamine receptors D1, D2, D3 and D5, and AT1 have been described with significant changes in receptor function or signaling (Table 1), it can therefore be suggested that B1R and dopaminergic receptors may interact through the regulation of processes associated with MAPK pathways.

Potential regulation of the B2R function by the D2like receptor can also be proposed. The first receptor acts through $G \alpha_{q}$ and activates PCL $\beta$, whereas this pathway is activated by the D2-like receptor through the G $\beta \gamma$ subunit. The activated PLC $\beta$ induces $\mathrm{Ca}^{2+}$ release, which mediates NO production, modulating several processes, such as vasodilatation or vasoconstriction (Leeb-Lunberg et al., 2005). Hence, the interaction between these receptors could be responsible for the appearance of effects related to $\mathrm{Ca}^{2+}$-mediated functions. Indeed, in a study performed on neuroblastoma cell line SH-SY5Y, an interaction of B2R with dopamine receptors was proposed (Hong et al., 2004). Haloperidol, an agonist of dopamine receptors, inhibits the intracellular $\mathrm{Ca}^{2+}$ release induced synergistically by bradykinin and neurosteroids or by bradykinin and sigma receptor agonists. In that report, the formation of oligomeric patterns involving GPCRs was suggested. Recently, a NO-mediated antidepressant effect of aripiprazole, a specific D2R agonist, has been demonstrated (Shafaroodi et al., 2015). Therefore, despite the fact that there is no direct evidence of the formation of heterodimers composed of $\mathrm{B} 2 \mathrm{R}$ and dopamine receptors, the observations described above allow us to propose their existence.

A probable regulation of the functions of kinin and dopamine receptors through $\beta$-arrestin seems to be interesting if one considers the importance of these proteins in the trafficking and maintenance of receptors in membranes. The $\beta$-arrestin-mediated signaling of dopaminergic receptors involves the Akt/GSK-3 pathway. Kinin receptors are also able to activate Akt signalization but through both $G \alpha_{\mathrm{q}}$ and G $\beta \gamma$ (Leeb-Lundberg et al., 2005). It has even been demonstrated that the tyrosine kinase Akt mediates the cardioprotective impact of bradykinin during preconditioned ischemia but a clear evidence of $\beta$-arrestin participation in this effect has not been presented (Sharma et al., 2015). To date, the cooperation of $\beta$-arrestin with kinin receptors seems to be associated with protein internalization and receptor desensitization but not with direct signaling. Nevertheless, it cannot be excluded that signaling changes may be the result of receptor dimerization, which causes disturbances in its internalization.

An emerging trend in the understanding of the functions of GPCRs is associated with its oligomerization, even hetero-oligomerization. The facts summarized above, concerning similar signaling of dopamine and kinin receptors, indicate that assembling of these proteins in cellular membrane may occur and that such reorganization could result in changes in signal transduction or even in agonist binding. Recently, there is increasing interest in research that relates to the allosteric modulation of dimerized GPCRs, including kinin and dopamine receptors (Sharma, 2014; Beaulieu et al., 2015). These observations provide further evidence that a crosstalk between kinin and dopamine receptors is possible and can be useful in the regulation of many cellular processes. Generally, numerous cellular processes are mediated by kinin or dopamine receptors. Their activation regulates a variety of physiological functions whose disturbance leads to systemic pathologies. In addition, ample evidence suggests that the interference in the signaling of the dopaminergic receptors and kinin receptors may occur. Therefore, the participation of kinin and dopamine receptors in the regulation of common processes argues in favor of mutual cooperation.

\section{SUMMARY}

On the basis of the reports summarized hereby, concerning similar signaling of kinin and dopamine receptors, the hypothesis of cooperation between them seems to be possible. Further studies focused on the elucidation which element of this cooperation can be related to 
the cross-talk of signaling pathways of independent receptors or to the direct interactions between receptors should be performed. The kinin and dopamine receptors are widely co-expressed in tissues, regulating often the same processes. In recent years, the researchers' interest in GPCRs has rapidly increased because these transmembrane receptors possess a common signal transduction system and act as controllers of diverse physiological processes. Therefore, these proteins represent important targets for the development of new drug candidates with potential therapeutic applications.

\section{Declaration of interest}

The authors report no conflicts of interest.

\section{Acknowledgements}

Faculty of Biochemistry, Biophysics and Biotechnology of Jagiellonian University is a partner of the Leading National Research Center (KNOW) supported by the Ministry of Science and Higher Education.

\section{REFERENCES}

Abadir PM, Periasamy A, Carey RM, Siragy HM (2006) Angiotensin II type 2 receptor-bradykinin $\mathrm{B} 2$ receptor functional heterodimerization. Hypertension 48: 316-322. http://dx.doi.org/10.1161/01. HYP.0000228997.88162.a8.

AbdAlla S, Zaki E, Lother H, Quitterer U (1999) Involvement of the amino terminus of the $\mathrm{B}(2)$ receptor in agonist-induced receptor dimerization. J Biol Chem 274: 26079-26084. http://dx.doi. org/10.1074/jbc.274.37.26079.

AbdAlla S, Lother H, Quitterer U (2000) AT1-receptor heterodimers show enhanced $\mathrm{G}$-protein activation and altered receptor sequestration. Nature 407: 94-98. http://dx.doi.org/10.1038/35024095.

AbdAlla S, Abdel-Baset A, Lother H, el Massiery A, Quitterer U (2005) Mesangial AT1/B2 receptor heterodimers contribute to angiotensin II hyperresponsiveness in experimental hypertension. J Mol Neurosic 26: 185-192. http://dx.doi.org/10.1385/JMN/26:02:185.

Agnati LF, Ferre S, Lluis C, Franco R, Fuxe K (2003) Molecular mechanisms and therapeutical implications of intramembrane receptor/ receptor interactions among heptahelical receptors with examples from the striatopallidal GABA Neurons. Pharmacol Rev 55: 509-550. http://dx.doi.org/10.1124/pr.55.3.2.

Anderson GR, Cao Y, Davidson S, Truong HV, Pravetoni M, Thomas MJ, Wickman K, Giesler GJ Jr, Martemyanov KA (2010) R7BP complexes with RGS9-2 and RGS7 in the striatum differentially control motor learning and locomotor responses to cocaine. Neuropsychopharmacology 35: 1040-1050. http://dx.doi.org/10.1038/ npp. 2009.212.

Austin CE, Faussner A, Robinson HE, Chakravarty S, Kyle DJ, Bathon JM, Proud D (1997) Stable expression of the human kinin B1 receptor in Chinese hamster ovary cells. J Biol Chem 272: 11420 11425. http://dx.doi.org/10.1074/jbc.272.17.11420.

Bai B, Liu L, Zhang N, Wang C, Jiang Y, Chen J (2014) Heterodimerization of human apelin and bradykinin 1 receptors: novel signal transduction characteristics. Cell Signal 26: 1549-1559. http://dx.doi. org/10.1016/j.cellsig.2014.03.022.

Barki-Harrington L, Bookout AL, Wang G, Lamb ME, Leeb-Lundberg LMF, Daaka Y (2003) Requirement for direct cross-talk between B1 and B2 kinin receptors for the proliferation of androgen-insensitive prostate cancer PC3 cells. Biochem J 371: 581-587. http://dx.doi. org/10.1042/BJ20021708.

Beaulieu JM, Gainetdinov RR (2005) The physiology, signaling, and pharmacology of dopamine receptors. Pharmacol Rev 63: 182-217. http://dx.doi.org/10.1124/pr.110.002642..

Beaulieu JM, Espinoza S, Gainetdinov RR (2015) Dopamine receptors - IUPHAR Review 13. Brit J Pharmacol 172: 1-23. http://dx.doi. org/10.1111/bph.12906.

Ben-Shmuel S, Danon A, Fleisher-Berkovich S (2013) Bradykinin decreases nitric oxide release from microglia via inhibition of cyclic adenosine monophosphate signaling. Peptides 40: 133-140. http:// dx.doi.org/10.1016/j.peptides.2013.01.006.

Blais C Jr, Marceau F, Roleau JL, Adam A (2000) The kallikrein-kininogen-kinin system: lessons for the quantification of endogenous kinins. Peptides 21: 1903-1940. http://dx.doi.org/10.1016/S01969781(00)00348-X.

Blaukat A (2003) Structure and signaling pathways of kinin receptors. Andrologia 35: 17-23. http://dx.doi.org/10.1046/j.14390272.2003.00533.x.
Borroto-Escuela DO, Romero-Fernandez W, Tarakanov AO, Marcellino D, Ciruela F, Agnati LF, Fuxe K (2010) Dopamine D2 and 5-hydroxytryptamine 5-HT( $\left.{ }_{2} \mathrm{~A}\right)$ receptors assemble into functionally interacting heteromers. Biochem Biophys Res Commun 401: 605-610. http://dx.doi.org/10.1016/j.bbrc.2010.09.110.

Borroto-Escuela DO, Van Craenenbroeck K, Romero-Fernandez W, Guidolin D, Woods AS, Rivera A, Haegeman G, Agnati LF, Tarakanov AO, Fuxe K (2011) Dopamine D2 and D4 receptor heterodimerization and its allosteric receptor-receptor interactions. Biochem Biophys Res Commun 404: 928-934. http://dx.doi.org/10.1016/j. bbrc.2010.12.083.

Borroto-Escuela DO, Pintsuk J, Schafer T, Friedland K, Ferraro L, Tanganelli S, Liu F, Fuxe K (2016) Multiple D2 heteroreceptor complexes: new targets for treatment of schizophrenia. Ther Adv Psychopbarmacol 6: 77-94. http://dx.doi.org/10.1177/2045125316637570.

Bouvier M (2001) Oligomerization of G-protein-coupled transmitter receptors. Nat Rev Neurosci 2: 274-286. http://dx.doi. org/10.1038/35067575.

Bulenger S, Marullo S, Bouvier M (2005) Emerging role of homoand heterodimerization in G-protein-coupled receptor biosynthesis and maturation. Trends Pharmacol Sci 26: 131-137. http://dx.doi. org/10.1016/j.tips.2005.01.004

Camps M, Carozzi A, Schnabel P, Scheer A, Parker PJ, Gierschik P (1992) Isozyme-selective stimulation of phospholipase C-beta 2 by G-protein beta gamma-subunits. Nature 360: 684-686. http:// dx.doi.org/10.1038/360684a0.

Canals M, Marcellino D, Fanelli F, Ciruela F, de Benedetti P, Goldberg SR, Neve K, Fuxe K, Agnati LF, Woods AS, Ferre S, Lluis C, Bouvier M, Franco R (2003) Adenosine A2A-dopamine D2 receptor-receptor heterodimerization: qualitative and quantitative assessment by fluorescence and bioluminescence energy transfer. J Biol Chem 278: 46741-46749. http://dx.doi.org/10.1074/jbc.M306451200.

De Brito Gariepy HDB, Carayon P, Ferrari B, Couture R (2010) Contribution of the central dopaminergic system in the anti-hypertensive effect of kinin B1 receptor antagonists in two rat models of hypertension. Neuropeptides 44: 191-198. http://dx.doi.org/10.1016/j. npep.2009.12.011.

Del'Guidice T, Lemasson M, Beaulieu JM (2011) Role of beta-arrestin 2 downstream of dopamine receptors in the basal ganglia. Front Neuroanat 5: 58. http://dx.doi.org/10.3389/fnana.2011.00058.

Dupre DJ, Hebert TE (2006) Biosynthesis and trafficking of seven transmembrane receptor signalling complexes. Cell Signal 18: 1549_1559. http://dx.doi.org/10.1016/j.cellsig.2006.03.009.

Dziedzicka-Wasylewska M, Faron-Górecka A, Andrecka J, Polit A, Kuśmider M, Wasylewski Z (2006) Fluorescence studies reveal heterodimerization of dopamine D1 and D2 receptors in the plasma membrane. Biochemistry 45: 8751-8759. http://dx.doi.org/10.1021/ bi060702m.

Enquist J, Sanden C, Skroder C, Mathis SA, Leeb-Lundberg LMF (2014) Kinin-stimulated B1 receptor signaling depends on receptor endocytosis whereas B2 receptor signaling does not. Neurochem Res 39: 1037-1047. http://dx.doi.org/10.1007/s11064-013-1126-9.

Espinoza S, Salahpour A, Masri B, Sotnikova TD, Messa M, Barak LS, Caron MG, Gainetdinov RR (2011) Functional interaction between trace amine-associated receptor 1 and dopamine D2 receptor. Mol Pharmacol 80: 416-425. http://dx.doi.org/10.1124/mol.111.073304.

Ferrada C, Ferre S, Casado V, Cortes A, Justinova Z, Barnes C, Canela EI, Goldberg SR, Leurs R, Lluis C, Franco R (2008) Interactions between histamine $\mathrm{H} 3$ and dopamine D2 receptors and the implications for striatal function. Neuropharmacology 55: 190-197. http:// dx.doi.org/10.1016/j.neuropharm.2008.05.

Ferrada C, Moreno E, Casado V, Bongers G, Cortes A, Mallol J, Canela EI, Leurs R, Ferre S, Lluis C, Franco R (2009) Marked changes in signal transduction upon heterodimerization of dopamine D1 and histamine H3 receptors. Br J Pharmacol 157: 64-75. http://dx.doi. org/10.1111/j.1476-5381.2009.00152.x.

Ferre S, Casado V, Devi LA, Filizola M, Jockers R, Lohse MJ, Milligan G, Pin JP, Guitart X (2014) G protein-coupled receptor oligomerization revisited: functional and pharmacological perspectives. Pharmacol Rev 66: 413-434. http://dx.doi.org/10.1124/pr.113.008052.

Figueroa CD, Ehrenfeld P, Bhoola KD (2012) Kinin receptors as targets for cancer therapy. Exp Opin Ther Targets 16: 299-312. http:// dx.doi.org/10.1517/14728222.2012.662957.

Ghosh E, Kumari P, Jaiman D, Shukla AK (2015) Methodological advances: the unsung heroes of the GPCR structural revolution. Nat Rev Mol Cell Biol 16: 69-81. http://dx.doi.org/10.1038/nrm3933.

Gildea JJ, Wang X, Shah N, Tran H, Spinosa M, Van Sciver R, Sasaki M, Yatabe J, Carey RM, Jose PA, Felder RA (2012) Dopamine and angiotensin type 2 receptors cooperatively inhibit sodium transport in human renal proximal tubule cells. Hypertension 60: 396-403. http://dx.doi.org/10.1161/HYPERTENSIONAHA.112.194175.

Gines S, Hillion J, Torvinen M, Le Crom S, Casado V, Canela EI, Rondin S, Lew JY, Watson S, Zoli M, Agnati LF, Verniera P, Lluis C, Ferre S, Fuxe K, Franco R (2000) Dopamine D1 and adenosine A1 receptors form functionally interacting heteromeric complexes. 
Proc Natl Acad Sci USA 97: 8606-8611. http://dx.doi.org/10.1073/ pnas. 150241097

Gonzalez S, Rangel-Barajas C, Peper M, Lorenzo R, Moreno E, Ciruela F, Borycz J, Ortiz J, Lluis C, Franco R, McCormick PJ, Volkow ND, Rubinstein M, Floran B, Ferre S (2012a) Dopamine D4 receptor, but not the ADHD-associated D4.7 variant, forms functional heteromers with the dopamine D2S receptor in the brain. Mol Psychiatry 17: 650-662. http://dx.doi.org/10.1038/mp.2011.93.

Gonzalez S, Moreno-Delgado D, Moreno E, Perez-Capote K, Franco R, Mallol J, Cortes A, Casado V, Lluis C, Ortiz J, Ferre S, Canela E, McCormick PJ (2012b) Circadian-related heteromerization of adrenergic and dopamine $\mathrm{D}(4)$ receptors modulates melatonin synthesis and release in the pineal gland. PLoS Biol 10: e1001347. http://dx.doi.org/10.1371/journal.pbio.1001347.

Greengard P (2001) The neurobiology of slow synaptic transmission. Science 294: 1024-1030. http://dx.doi.org/10.1126/science.294.5544.1024.

Guevara-Lora I, Florkowska M, Kozik A (2009) Bradykinin-related peptides up-regulate the expression of kinin B1 and B2 receptor genes in human promonocytic cell line U937. Acta Biochim Pol 56: 515-522.

Guevara-Lora I, Majkucinska M, Barbasz A, Faussner A, Kozik A (2011) Kinin generation from exogenous kininogens at the surface of retinoic acid-differentiated human neuroblastoma IMR-32 cells after stimulation with interferon- $\gamma$. Peptides 32: 1193-1200. http:// dx.doi.org/10.1016/j.peptides.2011.04.019.

Guevara-Lora I (2012) Kinin-mediated inflammation in neurodegenerative disorders. Neurochem Int 61: 72-78. http://dx.doi.org/10.1016/j. neuint.2012.04.013.

Guevara-Lora I, Blonska B, Faussner A, Kozik A (2013) Kinin-generating cellular model obtained from human glioblastoma cell line U373. Acta Biochim Pol 60: 299-305..

Han Y, Moreira IS, Urizar E, Weinstein H, Javitch JA (2009) Allosteric communication between protomers of dopamine class A GPCR dimers modulates activation. Nat Chem Biol 5: 688-695. http://dx.doi. org/10.1038/nchembio.199.

Hisahara S, Shimohama S (2011) Dopamine receptors and Parkinson's disease. Int J Med Chem 2011: 403039. http://dx.doi. org/10.1155/2011/403039.

Hong W, Nuwayhid SJ, Werling LL (2004) Modulation of bradykinininduced calcium changes in SH-SY5Y cells by neurosteroids and sigma receptor ligands via a shared mechanism. Synapse 54: 102-110. http://dx.doi.org/10.1002/syn.20069.

Joseph K, Kaplan AP (2005) Formation of bradykinin: a major contribution to the innate inflammatory response. Adv Immunol 86: 159208. http://dx.doi.org/10.1016/S0065-2776(04)86005-X.

Kang DS, Ryberg K, Morgelin M, Leeb-Lundberg LMF (2004) Spontaneous formation of a proteolytic B1 and B2 bradykinin receptor complex with enhanced signaling capacity. J Biol Chem 279: 2210222107. http://dx.doi.org/10.1074/jbc.M402572200.

Kang DS, Gustafsson C, Morgelin M, Leeb-Lundberg LMF (2005) B1 bradykinin receptor homo-oligomers in receptor cell surface expression and signaling: effects of receptor fragments. Mol Pharmacol 67: 309-318. http://dx.doi.org/10.1124/mol.104.002840.

Kearn CS, Blake-Palmer K, Daniel E, Mackie K, Glass M (2005) Concurrent stimulation of cannabinoid CB1 and dopamine D2 receptors enhances heterodimer formation: a mechanism for receptor cross-talk? Mol Pharmacol 67: 1697-1704. http://dx.doi.org/10.1124/ mol.104.006882.

Kim KM, Valenzano KJ, Robinson SR, Yao WD, Barak LS, Caron MG (2001) Differential regulation of the dopamine D2 and D3 receptors by $G$ protein-coupled receptor kinases and beta-arrestins. J Biol Chem 276: 37409-37414. http://dx.doi.org/10.1074/jbc. M106728200.

Lavine N, Ethier N, Oak JN, Pei L, Liu F, Trieu P, Rebois RV, Bouvier M, Hebert TE, Van Tol HH (2002) G protein-coupled receptors form stable complexes with inwardly rectifying potassium channels and adenylyl cyclase. J Biol Chem 277: 46010-46019. http://dx.doi. org/10.1074/jbc.M205035200.

Lee FJ, Xue S, Pei L, Vukusic B, Chery N, Wang Y, Wang YT, Niznik $\mathrm{HB}$, Yu XM, Liu F (2002) Dual regulation of NMDA receptor functions by direct protein-protein interactions with the dopamine D1 receptor. Cell 111: 219-230. http://dx.doi.org/10.1016/S00928674(02)00962-5.

Lee SP, So CH, Rashid AJ, Varghese G, Cheng R, Lanca AJ, O’Dowd $\mathrm{BF}$, George SR (2004) Dopamine D1 and D2 receptor co-activation generates a novel phospholipase C-mediated calcium signal. J Biol Chem 279: 35671-35678. http://dx.doi.org/10.1074/jbc. M401923200.

Leeb-Lundberg LMF, Marceau F, Muller-Esterl W, Pettibone DJ, Zuraw BL (2005) International union of pharmacology. XLV. Classification of the kinin receptor family: from molecular mechanism to pathophysiological consequences. Pharmacol Rev 57: 27-77. http://dx.doi.org/10.1124/pr.57.1.2.

Leo D, Mus L, Espinoza S, Hoener MC, Sotnikova TD, Gainetdinov RR (2014) Taar1-mediated modulation of presynaptic dopa- minergic neurotransmission: role of D2 dopamine autoreceptors. Neuropharmacology 81: 283-291. http://dx.doi.org/10.1016/j.neuropharm.2014.02.007.

Li S, Wong AH, Liu F (2014) Ligand-gated ion channel interacting proteins and their role in neuroprotection. Front Cell Neurosci 8: 125. http://dx.doi.org/10.3389/fncel.2014.00125.

Liu XY, Chu XP, Mao LM, Wang M, Lan HX, Li MH, Zhang GC, Parelkar NK, Fibuch EE, Haines M, Neve KA, Liu F, Xiong ZG, Wang JQ (2006) Modulation of D2R-NR2B interactions in response to cocaine. Neuron 52: 897-909. http://dx.doi.org/10.1016/j.neuron.2006.10.011.

Łukasiewicz S, Faron-Górecka A, Dobrucki J, Polit A, Dziedzicka-Wasylewska M (2009) Studies on the role of the receptor protein motifs possibly involved in electrostatic interactions on the dopamine D1 and D2 receptor oligomerization. FEBS J 276: 760-775. http:// dx.doi.org/10.1111/j.1742-4658.2008.06822.x.

Łukasiewicz S, Polit A, Kędracka-Krok S, Wędzony K, Maćkowiak M, Dziedzicka-Wasylewska M (2010) Hetero-dimerization of serotonin 5-HT(2A) and dopamine D(2) receptors. Biochim Biophys Acta 1803: 1347-1358. http://dx.doi.org/10.1016/j.bbamcr.2010.08.010.

Marceau F, Sabourin T, Houle S, Fortin JP, Petitclerc E, Molinaro G, Adam A (2002) Kinin receptors: functional aspects. Int Immunopharmacol 2: 1729-1739. http://dx.doi.org/10.1016/S15675769(02)00189-3.

Marceau F, Bouthillier J, Houle S, Sabourin T, Forin JP, Morissette G, Lodge R, Fortin S, Gaudreault RC, Bawolak MT, Koumbadinga GA, Roy C, Charest-Morin X, Gera L (2013) Bradykinin receptors: agonists, antagonist, expression, signaling and adaptation to sustained stimulation. I Angioedema 1: 1-9.

Marcellino D, Ferre S, Casado V, Cortes A, Le Foll B, Mazzola C, Drago F, Saur O, Stark H, Soriano A, Barnes C, Goldberg SR, Lluis C, Fuxe K, Franco R (2008) Identification of dopamine D1D3 receptor heteromers. Indications for a role of synergistic D1-D3 receptor interactions in the striatum. J Biol Chem 283: 26016-26025. http://dx.doi.org/10.1074/jbc.M710349200.

Martinez-Pinilla E, Rodriguez-Perez AI, Navarro G, Aguinaga D, Moreno E, Lanciego JL, Labandeira-Garcia JL, Franco R (2015) Dopamine D2 and angiotensin II type 1 receptors form functional heteromers in rat striatum. Biochem Pharmacol 96: 131-142. http:// dx.doi.org/10.1016/j.bcp.2015.05.006.

Maurice P, Kamal M, Jockers R (2011) Asymmetry of GPCR oligomers supports their functional relevance. Trends Pharmacol Sci 32: 514 520. http://dx.doi.org/10.1016/j.tips.2011.05.006

Meunier CN, Callebert J, Cancela JM, Fossier P (2015) Effect of dopaminergic D1 receptors on plasticity is dependent of serotoninergic 5-HT1A receptors in L5-pyramidal neurons of the prefrontal cortex. PLoS One 10: e0120286. http://dx.doi.org/10.1371/journal. pone.0120286.

Michineau S, Alhenc-Gelas F, Rajerison RM (2006) Human bradykinin $\mathrm{B} 2$ receptor sialylation and $\mathrm{N}$-glycosylation participate with disulfide bonding in surface receptor dimerization. Biochemistry 45: 2699-2707. http://dx.doi.org/10.1021/bi051674v.

Milligan G (2009) G protein-coupled receptor hetero-dimerization: contribution to pharmacology and function. $\mathrm{Br} J$ Pharmacol 158: 5-14. http://dx.doi.org/10.1111/j.1476-5381.2009.00169.x.

Milligan G (2013) The prevalence, maintenance, and relevance of G protein-coupled receptor oligomerization. Mol Pharmacol 84: 158169. http://dx.doi.org/10.1124/mol.113.084780.

Missale C, Nash SR, Robinson SW, Jaber M, Caron MG (1998) Dopamine receptors: from structure to function. Physiol Rev 78: 189-225.

Morand-Contant M, Anand-Srivastava MB, Couture R (2010) Kinin B1 receptor upregulation by angiotensin II and endothelin-1 in rat vascular smooth muscle cells: receptors and mechanisms. Am J Physiol Heart Circ Physiol 299: H1625-H1632. http://dx.doi.org/10.1152/ ajpheart.00735.2009.

Moreau ME, Garbacki N, Molinaro G, Brown NJ, Marceau F, Adam A (2005) The kallikrein-kinin system: current and future pharmacological targets. J Pharmacol Sci 99: 6-38. http://dx.doi.org/10.1254/ jphs.srj05001x.

Moreno E, Vaz SH, Cai N-S, Ferrada C, Quiroz C, Barodia S, Kabbani N, Canela EI, McCormick PJ, Lluis C, Franco R, Ribeiro JA, Sebastiao AM, Ferre S (2011a) Dopamine-galanin receptor heteromers modulate cholinergic neurotransmission in the rat ventral hippocampus. J Neurosci 31: 7412-7423. http://dx.doi.org/10.1523/ JNEUROSCI.0191-11.2011.

Moreno E, Hoffmann H, Gonzalez-Sepulveda M, Navarro G, Casado V, Cortes A, Mallol J, Vignes M, McCormick PJ, Canela EI, Lluis C, Moratalla R, Ferre S, Ortiz J, Franco R (2011b) Dopamine D1histamine $\mathrm{H} 3$ receptor heteromers provide a selective link to MAPK signaling in GABAergic neurons of the direct striatal pathway. J Biol Chem 286: 5846-5854. http://dx.doi.org/10.1074/jbc.M110.161489.

Nai Q, Li S, Wang SH, Liu J, Lee FJ, Frankland PW, Liu F (2010) Uncoupling the D1-N-methyl-D-aspartate (NMDA) receptor complex promotes NMDA dependent long-term potentiation and working memory. Biol Psychiatry 67: 246-254. http://dx.doi.org/10.1016/j. biopsych.2009.08.011. 
O’Dowd BF, Nguven T, Ji X, George SR (2013) D(5) dopamine receptor carboxyl tail involved in $\mathrm{D}(5)-\mathrm{D}(2)$ heteromer formation. Biochem Biophys Res Commun 431: 586-589. http://dx.doi.org/10.1016/j. bbrc.2012.12.139.

Perreault ML, Hasbi A, O'Dowd BF, George SR (2014) Heteromeric dopamine receptor signaling complexes: emerging neurobiology and disease relevance. Neuropsychopharmacology 39: 156-168. http://dx.doi. org/10.1038/npp.2013.148.

Peterson SM, Pack TF, Wilkins AD, Urs NM, Urban DJ, Bass CE, Lichtarge O, Caron MG (2015) Elucidation of G-protein and $\beta$-arrestin functional selectivity at the dopamine D2 receptor. Proc Natl Acad Sci USA 112: 7097-7102. http://dx.doi.org/10.1073/ pnas. 1502742112 .

Phagoo SB, Poole S, Leeb-Lundberg LMF (1999) Autoregulation of bradykinin receptors: agonists in the presence of interleukin-1beta shift the repertoire of receptor subtypes from B2 to B1 in human lung fibroblasts. Mol Pharmacol 56: 325-333. http://dx.doi. org $/ 10.1124 / \mathrm{mol} .56 .2 .325$.

Philip F, Sengupta P, Scarlata S (2007) Signaling through a G proteincoupled receptor and its corresponding $G$ protein follows a stoichiometrically limited model. J Biol Chem 282: 19203-19216. http:// dx.doi.org/10.1074/jbc.M701558200.

Polito M, Guiot E, Gangarossa G, Longueville S, Doulazmi M, Valjent E, Herve D, Girault JA, Paupardin-Tritsch D, Castro LR, Vincent P (2015) Selective effects of PDE10A inhibitors on striatopallidal neurons require phosphatase inhibition by DARPP-32. eNeuro 2: 1-15. http://dx.doi.org/10.1523/ENEURO.0060-15.2015.

Pou C, Mannoury la Cour C, Stoddart LA, Millan MJ, Milligan G (2012) Functional homomers and heteromers of dopamine D2L and D3 receptors co-exist at the cell surface. J Biol Chem 287: 88648878. http://dx.doi.org/10.1074/jbc.M111.326678.

Prado GN, Taylor L, Zhou X, Ricupero D, Mierke DF, Polgar P (2002) Mechanisms regulating the expression, self maintenance, and signaling-function of the bradykinin $\mathrm{B} 2$ and $\mathrm{B} 1$ receptors. I Cell Physiol 193: 275-286. http://dx.doi.org/10.1002/jcp.10175.

Prinster SC, Hague C, Hall RA (2005) Heterodimerization of G protein-coupled receptors: specificity and functional significance. Pharmacol Rev 57: 289-298. http://dx.doi.org/10.1124/pr.57.3.1.

Quitterer U, Pohl A, Langer A, Koller S, AbdAlla S (2011) A cleavable signal peptide enhances cell surface delivery and heterodimerization of Cerulean-tagged angiotensin II AT1 and bradykinin B2 receptor. Biochem Biophys Res Commun 409: 544-549. http://dx.doi. org/10.1016/j.bbrc.2011.05.041.

Rocheville M, Lange DC, Kumar U, Patel SC, Patel RC, Patel YC (2000) Receptors for dopamine and somatostatin: formation of hetero-oligomers with enhanced functional activity. Science 288: 154 157. http://dx.doi.org/10.1126/science.288.5463.154.

Sanden C, Leeb-Lundberg LMF (2013) Kinin B1 receptor homooligomerization is required for receptor trafficking to the cell surface. Int Immunopharmacol 15: 121-128. http://dx.doi.org/10.1016/j. intimp.2012.11.012.

Sassone-Corsi P (2012) The cyclic AMP pathway. Cold Spring Harb Perspect Biol 4: a011148. http://dx.doi.org/10.1101/cshperspect. a011148.

Scarselli M, Novi F, Schallmach E, Lin R, Baragli A, Colzi A, Griffon N, Corsini G, Sokoloff P, Levenson R, Vogel Z, Maggfio R (2001) D2/D3 dopamine receptor heterodimers exhibit unique functional properties. J Biol Chem 276: 30308-30314. http://dx.doi. org/10.1074/jbc.M102297200.

Shafaroodi H, Oveisi S, Hosseini M, Niknahad H, Moezi L (2015) The effect of acute aripiprazole treatment on chemically and electrically induced seizures in mice: The role of nitric oxide. Epilepsy Behav 48: 35-40. http://dx.doi.org/10.1016/i.vebeh.2015.05.018.

Sharma JN (2014) Basic and clinical aspects of bradykinin receptor antagonists. Prog Drug Res 69: 1-14. http://dx.doi.org/10.1007/978-3319-06683-7 1.

Sharma R, Randhawa PK, Singh N, Jaggi AS (2015) Bradykinin in ischemic conditioning-induced tissue protection: Evidences and possible mechanisms. Eur J Pharmacol 768: 58-70. http://dx.doi. org/10.1016/j.ejphar.2015.10.029.

Shenoy SK, Lefkowitz RJ (2011) $\beta$-Arrestin-mediated receptor trafficking and signal transduction. Trends Pharmacol Sci 32: 521-533. http://dx.doi.org/10.1016/j.tips.2011.05.002.

Smith NJ, Milligan G (2010) Allostery at G protein-coupled receptor homo- and heteromers: uncharted pharmacological landscapes. Pharmacol Rev 62: 701-725. http://dx.doi.org/10.1124/pr.110.002667.

So $\mathrm{CH}$, Verma V, Alijaniaram M, Cheng R, Rashid AJ, O'Dowd BF, George SR (2009) Calcium signaling by dopamine D5 receptor and D5-D2 receptor hetero-oligomers occurs by a mechanism distinct from that for dopamine. D1-D2 receptor hetero-oligomers. Mol Pharmacol 75: 843-854. http://dx.doi.org/10.1124/mol.108.051805.

Tadagaki K, Jockers R, Kamal M (2012) History and biological significance of GPCR heteromerization in the neuroendocrine system. Neuroendocrinology 95: 223-231. http://dx.doi. org $/ 10.1159 / 000330000$.

Taymans JM, Leysen JE, Langlois X (2003) Striatal gene expression of RGS2 and RGS4 is specifically mediated by dopamine D1 and D2 receptors: clues for RGS2 and RGS4 functions. J Neurochem 84 : 1118-1127. http://dx.doi.org/10.1046/j.1471-4159.2003.01610.x.

Tiberi M, Nash SR, Bertrand L, Lefkowitz RJ, Caron MG (1996) Differential regulation of dopamine D1A receptor responsiveness by various G protein-coupled receptor kinases. J Biol Chem 271: 37713778. http://dx.doi.org/10.1074/jbc.271.7.3771.

Thomsen W, Frazer J, Unett D (2005) Functional assays for screening GPCR targets. Curr Opin Biotecbnol 16: 655-665. http://dx.doi. org/10.1016/j.copbio.2005.10.008.

Toda S, Alguacil LF, Kalivas PW (2003) Repeated cocaine administration changes the function and subcellular distribution of adenosine A1 receptor in the rat nucleus accumbens. J Neurocbem 87: 14781484. http://dx.doi.org/10.1046/j.1471-4159.2003.02121.x.

Urs NM, Snyder JC, Jacobsen JP, Peterson SM, Caron MG (2012) Deletion of GSK3 $\beta$ in D2R-expressing neurons reveals distinct roles for $\beta$-arrestin signaling in antipsychotic and lithium action. Proc Natl Acad Sci USA 109: 20732-20737. http://dx.doi.org/10.1073/ pnas.1215489109.

Vallone D, Picetti R, Borrelli E (2000) Structure and function of dopamine receptors. Neurosci Biobehav Rev 24: 125-132. http://dx.doi. org/10.1016/S0149-7634(99)00063-9.

Xie P, Browning DD, Hay N, Mackman N, Ye RD (2000) Activation of NF-kappa B by bradykinin through a Galpha(q)- and Gbeta gamma-dependent pathway that involves phosphoinositide 3-kinase and Akt. J Biol Chem 275: 24907-24914.

Yan Z, Song WJ, Surmeier J (1997) D2 dopamine receptors reduce Ntype $\mathrm{Ca}^{2+}$ currents in rat neostriatal cholinergic interneurons through a membrane delimited, protein-kinase-C-insensitive pathway. J Neurophysiol 77: 1003-1015.

Yu C, Yang Z, Ren H, Zhang Y, Han Y, He D, Lu Q, Wang X, Wang $X$, Yang C, Asico LD, Hopfer U, Eisner GM, Jose PA, Zeng C (2009) D3 dopamine receptor regulation of ETB receptors in renal proximal tubule cells from WKY and SHRs. Am J Hypertens 22: 877-883. http://dx.doi.org/10.1038/ajh.2009.80.

Zamponi GW, Currie KP (2013) Regulation of $\mathrm{Ca}(\mathrm{V}) 2$ calcium channels by $G$ protein coupled receptors. Biocbim Biophys Acta 1828: 1629-1643. http://dx.doi.org/10.1016/j.bbamem.2012.10.004.

Zeng C, Wang D, Yang Z, Wang Z, Asico LD, Wilcox CS, Eisner GM, Welch WJ, Felder RA, Jose PA (2004) Dopamine D1 receptor augmentation of D3 receptor action in rat aortic or mesenteric vascular smooth muscles. Hypertension 43: 673-679. http://dx.doi. org/10.1161/01.HYP.0000118958.27649.6f.

Zeng C, Yang Z, Wang Z, Jones J, Wang X, Altea J, Mangrum AJ, Hopfer U, Sibley DR, Eisner GM, Felder RA, Jose PA (2005a) Interaction of angiotensin II type 1 and D5 dopamine receptors in renal proximal tubule cells. Hypertension 45: 804-810. http://dx.doi. org/10.1161/01.HYP.0000155212.33212.99.

Zeng C, Wang Z, Hopfer U, Asico LD, Eisner GM, Felder RA, Jose PA (2005b) Rat strain effects of AT1 receptor activation on D1 dopamine receptors in immortalized renal proximal tubule cells. Hypertension 46: 799-805. http://dx.doi.org/10.1161/01. HYP.0000184251.01159.72.

Zeng C, Liu Y, Wang Z, He D, Huang L, Yu P, Zheng S, Jones JE, Asico LD, Hopfer U, Eisner GM, Felder RA, Jose PA (2006) Activation of D3 dopamine receptor decreases angiotensin II type 1 receptor expression in rat renal proximal tubule cells. Circ Res 99: 494-500. http://dx.doi.org/10.1161/01.RES.0000240500.96746.ec.

Zhang M, Fei XW, He YL, Yang G, Mei YA (2009) Bradykinin inhibits the transient outward $\mathrm{K}^{+}$current in mouse Schwann cells via the cAMP/PKA pathway. Am J Physiol Cell Physiol 296: C1364-C1372. http://dx.doi.org/10.1152/ajpcell.00014.2009.

Zhang X, Brovkovych V, Zhang Y, Tan F, Skidgel RA (2015) Downregulation of kinin B1 receptor function by B2 receptor heterodimerization and signaling. Cell Signal 27: 90-103. http://dx.doi. org/10.1016/j.cellsig.2014.

Zhu YM, Bradbury DA, Pang L, Knox AJ (2003) Transcriptional regulation of interleukin (IL)- 8 by bradykinin in human airway smooth muscle cells involves prostanoid-dependent activation of AP-1 and nuclear factor (NF)-IL-6 and prostanoid-independent activation of NF-kB. J Biol Chem 278: 29366-29375. http://dx.doi.org/10.1074/ jbc.M301785200. 